\title{
Role of silicon as a limiting nutrient to Antarctic diatoms: evidence from kinetic studies in the Ross Sea ice-edge zone
}

\author{
David M. Nelson ${ }^{1}$, Paul Tréguer ${ }^{2}$ \\ ${ }^{1}$ College of Oceanography, Oregon State University, Corvallis, Oregon 97331 USA \\ ${ }^{2}$ Institut d'Études Marines, Université de Bretagne Occidentale, 6 ave. V. le Gorgeu, F-29287 Brest Cedex, France
}

\begin{abstract}
During the austral summer of 1990 an intense, diatom-dominated, ice-edge phytoplankton bloom in the southwestern Ross Sea resulted in depletion of silicic acid, nitrate and phosphate to concentrations much lower than is typical for Antarctic surface waters. Silicic acid was depleted to $<6 \mu \mathrm{M}$ within the core of the meltwater field, where biogenic particulate silica concentrations exceeded $20 \mu \mathrm{mol} \mathrm{l}^{-1}$ Three Si uptake kinetic experiments were conducted on natural phytoplankton assemblages from the nutrient-depleted zone; ${ }^{30} \mathrm{Si}$-labeled $\mathrm{Si}(\mathrm{OH})_{4}$ was used to measure the uptake rate at concentrations ranging from 1 to $20 \mu \mathrm{M}$ above ambient. Dependence of the specific uptake rate $(V)$ on silicic acid concentration conformed well to a Michaelis-Menten saturation model; maximum uptake rates $\left(V_{\max }\right)$ ranged from 0.0022 to $0.0028 \mathrm{~h}^{-1}$ which corresponds to maximum growth rates of 0.08 to 0.10 doublings $\mathrm{d}^{-1}$. Half-saturation constants $\left(k_{m}\right)$ ranged from 1.1 to $4.6 \mu \mathrm{M}$, a range similar to values found in other areas of the ocean and considerably lower than those previously reported for several Antarctic diatom species in culture studies. Results indicate detectable, but weak, substrate limitation of silicic acid uptake rate by the naturally occurring diatom assemblage in the western Ross Sea. Significant Si limitation in other subsystems of the Southern Ocean would be possible only if their resident diatom assemblages had much lower affinity for silicic acid than we observed.
\end{abstract}

\section{INTRODUCTION}

The question of what limits the growth rates of Antarctic phytoplankton is still a matter of debate. Among the possible limiting factors (including temperature, light, nutrient supply, dissolved organic matter and trace metals) the macronutrients nitrogen, phosphorus and silicon have usually been ruled out because of their high concentrations in Antarctic and subantarctic surface waters. The question most often considered has not been whether macronutrients are limiting, but rather what conditions prevent them from being depleted to limiting concentrations (e.g. Jacques \& Tréguer 1986, Martin et al. 1990, Smith \& Sakshaug 1990).

The view of a uniformly nutrient-replete Southern Ocean may be an oversimplification, as the distributions of the major nutrients differ greatly in the different subsystems of the region (e.g. Gordon et al. 1986,
Tréguer \& Jacques unpubl.). Silicic acid concentrations, in particular, exhibit dramatic differences: in openocean areas that experience seasonal advance and retreat of pack ice, silicic acid concentrations are typically 60 to $90 \mu \mathrm{M}$, but in the permanently ice-free waters near the polar frontal zone silicic acid concentrations in the surface layer are generally $<10 \mu \mathrm{M}$ in summer (e.g. Le Jehan \& Tréguer 1983). Moreover, it has been shown that intense diatom blooms in summer can deplete nitrate and phosphate to the detection limit of conventional colorimetric analyses, and silicic acid to $<10 \mu \mathrm{M}$, in the marginal ice zone of the Ross Sea (Nelson \& Smith 1986); substantial nutrient depletion (though not to detection-limit levels) has also been observed near the Antarctic Peninsula (Holm-Hansen et al. 1989, Holm-Hansen \& Mitchell 1991). These low concentrations present the possibility of nutrient limitation, especially if Antarctic phytoplankton species are not well adapted to nutrient-depleted environments. 
Kinetic studies of the concentration dependence of silicic acid uptake, and of the silicon-limited growth of diatoms, have given results for Antarctic species that differ greatly from those obtained for diatoms from other regions. For diatoms from all areas of the ocean examined to date the dependence of the specific uptake rate of silicic acid $(V)$ and the division rate $(\mu)$ on the extracellular silicic acid concentration can be fit reasonably well by hyperbolic saturation functions of the form of the Michaelis-Menten equation for enzyme kinetics or the Monod equation for the substratelimited growth of bacteria (e.g. Paasche 1973a, b, Nelson et al. 1976, Nelson \& Brzezinski 1990):

$$
\begin{aligned}
& V=V_{\max } \frac{\left[\mathrm{Si}(\mathrm{OH})_{4}\right]}{k_{m}+\left[\mathrm{Si}(\mathrm{OH})_{4}\right]} \\
& \mu=\mu_{\max } \frac{\left[\mathrm{Si}(\mathrm{OH})_{4}\right]}{k_{s}+\left[\mathrm{Si}(\mathrm{OH})_{4}\right]}
\end{aligned}
$$

where $V_{\max }$ represents the maximum uptake rate, $\mu_{\max }$ the maximum growth rate and $k_{m}$ and $k_{s}$ the silicic acid concentrations that respectively limit $V$ and $\mu$ to $1 / 2$ of their maximum values. Eqs. (1) \& (2) would be equivalent only if the cellular Si content were independent of the degree of $\mathrm{Si}$ limitation. A common result of culture studies has been that $k_{m}$ significantly exceeds $k_{s}$ (Nelson unpubl.). This inequality means that Eqs. (1) $\&$ (2) diverge at silicic acid concentrations low enough to limit the uptake rate, with cells lowering their degree of silicification so that growth rates close to $\mu_{\max }$ can be sustained in spite of the decreased Si availability. Ecologically this would imply that Si limitation of diatom growth rates is generally less severe than limitation of the uptake rate.

Kinetic results obtained on diatom cultures isolated from the Antarctic (Jacques 1983), and on nearmonocultures derived from natural Antarctic phytoplankton growing at temperatures realistic for the
Southern Ocean (Sommer 1986, 1991), have conformed reasonably well to Eqs. (1) \& (2). However the reported $k_{m}$ and $k_{s}$ values, ranging from 4 to $89 \mu \mathrm{M}$ (Table 1), are in general 3 to 100 times higher than those reported for diatoms from other parts of the ocean (e.g. Guillard et al. 1973, Conway \& Harrison 1977, Olsen \& Paasche 1986). Thus the Antarctic diatoms may exhibit a much lower affinity for silicate than do diatoms from other sectors of the world's oceans. This result suggests that silicic acid uptake and diatom growth could be limited by a silicic acid deficiency at concentrations that are normally (and accurately) thought to be saturating everywhere else in the ocean. Limitation of this kind is at least possible in 3 identifiable subsystems of the Southern Ocean where localized depletion to $<20 \mu \mathrm{M}$ has been reported (e.g. Le Jehan \& Tréguer 1983, Tréguer \& Jacques unpubl.): the polar frontal zone (including permanently ice-free waters immediately to the south), the marginal ice zone and certain nearshore areas. Diatoms exhibiting the lowest reported affinities for silicic acid $\left[k_{m}\right.$ or $k_{s}$ values

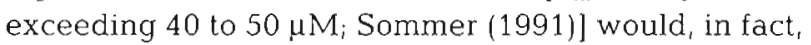
experience some degree of silicon limitation at even the highest surface concentrations observed in the Southern Ocean.

Methodological difficulties have prevented field study of the Si-limited growth kinetics of diatoms in natural ocean habitats, but the kinetics of silicic acid uptake have been examined in natural assemblages of diatom-dominated phytoplankton in several regions of the ocean (e.g. Goering et al. 1973, Azam \& Chisholm 1976, Nelson et al. 1981. Nelson \& Brzezinski 1990). These studies have shown the Michaelis-Menten hyperbola (Eq. 1) to fit the data reasonably well, with $k_{m}$ values very similar to those obtained for unialgal diatom cultures in laboratory studies. To date, field studies of silicic acid uptake kinetics have not been reported from natural diatom assemblages in the

Table 1. Half-saturation constants for silicic acid uptake $\left(k_{m}\right)$ or silicon-limited growth $\left(k_{s}\right)$ reported from culture studies of

\begin{tabular}{|c|c|c|c|}
\hline Species & $\begin{array}{c}k_{m} \\
(\mu \mathrm{M})\end{array}$ & $\begin{array}{c}k_{\mathrm{s}} \\
(\mu \mathrm{M})\end{array}$ & Source \\
\hline Nitzschia turgiduloides & 22.0 & - & Jacques (1983) \\
\hline Nitzschia kerguelensis ${ }^{\text {a }}$ & 12.0 & 88.7 & Jacques (1983), Sommer (1986) \\
\hline Nitzschia cylindrus & - & 8.4 & Sommer $(1986)$ \\
\hline Corethron criophilum & - & 60.1 & Sommer (1986) \\
\hline Corethron criophilum & - & 34.5 & Sommer (1991) \\
\hline Thalassiosira subtilis & - & 5.7 & Sommer (1986) \\
\hline Thalassiosira cf antarctica & - & 4.2 & Sommer (1991) \\
\hline Chaetoceros neglectum & - & 21.7 & Sommer (1986) \\
\hline Range for low-latitude species & $0.4-5.0$ & $0.02-1.4$ & Nelson (unpubl.) ${ }^{\mathrm{b}}$ \\
\hline
\end{tabular}
Southern Ocean diatoms, in comparison with those for diatom species isolated from temperate or tropical oceans 
Southern Ocean, where the culture data suggest that the diatoms may exhibit exceptionally low affinity for silicic acid (high $k_{m}$ values), and thus be limited in situ by silicic acid avallability. This paper reports the results of kinetic studies of silicic acid uptake by natural assemblages of Antarctic diatoms, conducted in the marginal ice zone of the western Ross Sea in the late austral summer of 1990 . The aims of this study were to measure directly the degree of Si limitation in that system and to assess the likelihood that Si plays a significant limiting role in other major subsystems of the Southern Ocean.

\section{METHODS}

All data were collected over 3 d ( 3 to 5 February 1990) in the southwestern Ross Sea aboard the RV 'Polar Duke'. Station locations are shown in Fig. 1. On 3 \& 4 February we determined the spatial distributions of temperature, salinity, nutrient concentrations (nitrate, nitrite, ammonium, phosphate and silicic acid) and biogenic particulate silica in the upper $60 \mathrm{~m}$ along a $260 \mathrm{~km}$ transect through the ice-edge zone. Sampling and analytical methods were as described by Nelson et al. (1989). This sampling occurred during the last week of a $30 \mathrm{~d}$ occupation of the study area, and a persistent ice-edge diatom bloom had been observed in the southwestern Ross Sea from early January through early February (Nelson et al. 1991). This bloom had produced local minima in all nutrient concentrations throughout the month (see Fig. 2), and was very similar in its general features to an ice-edge phytoplankton bloom examined during late January and early February 1983 (e.g. Smith \& Nelson 1985, Nelson \& Smith 1986). However, the surface nutrient concentrations within the core of the bloom decreased

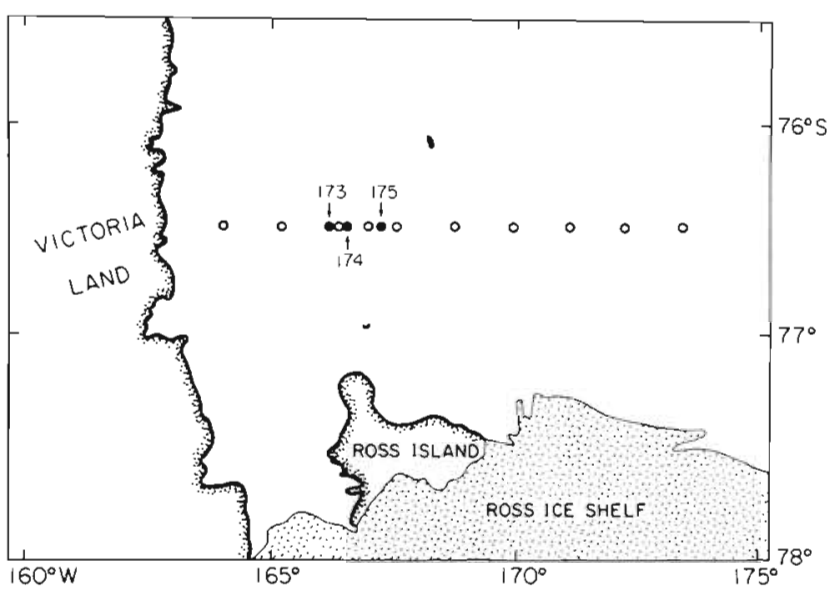

Fig. 1. Locations where $(0)$ transect data were collected and $(\bullet)$ surface water was collected tor ${ }^{30} \mathrm{Si}$ kinetic experiments with time during the late January-early February period and those encountered on 4 February (see 'Results') were the lowest observed during the month of our observations.

On the morning of 5 February we initiated ${ }^{30} \mathrm{Si}$ tracer experiments to measure the concentration dependence of silicic acid uptake rates by the resident natural diatom assemblage at each of 3 locations within the high-biomass, low-nutrient region of the ice-edge bloom (see Fig. 1). At each location a single seawater sample was collected at a depth of $1 \mathrm{~m}$ in a 121 Niskin bottle and transferred in its entirety to a $20 \mathrm{l}$ polypropylene spigoted carboy from which subsamples were drawn for individual measurements. This carboy was kept well agitated during subsampling to maintain a homogeneous suspension of phytoplankton cells and other particulate matter. A $50 \mathrm{ml}$ subsample for nutrient analysis was collected first, and analyzed on an Alpkem RFA-II continuous, segmented-flow analyzer as the other subsamples were being drawn. Each ${ }^{30} \mathrm{Si}$ kinetic experiment was initiated within $30 \mathrm{~min}$ after the seawater was collected, after confirming from initial RFA peak-height data that the silicic acid concentration was $<8 \mu \mathrm{M}$.

For each kinetic experiment a series of eight $1.0 \mathrm{l}$ subsamples was drawn into clear polycarbonate incubation bottles and ${ }^{30} \mathrm{Si}(\mathrm{OH})_{4}\left(92.61\right.$ at. $\left.\%{ }^{30} \mathrm{Si}\right)$ was added at concentrations of 1.0, 2.0,4.0,6.0, 8.0, 10.0, 15.0 and $20.0 \mu \mathrm{M}$. Samples were incubated for 24 to $26 \mathrm{~h}$ in an on-deck incubator that maintained seasurface temperature $\left(\mathrm{ca}-1{ }^{\circ} \mathrm{C}\right)$ by continuous flow of surface seawater. Irradiance was maintained at $50 \%$ of its sea-surface value by placing the samples inside acrylic tubes lined with neutral-density nickelcadmium screens (Perforated Products, Inc. \#145). At the end of the incubation period each sample was vacuum-filtered through a $0.6 \mu \mathrm{m}$ polycarbonate membrane filter (Nuclepore, Inc.), and the filter was folded in quarters, placed in a plastic petri dish and dried at $60^{\circ} \mathrm{C}$ for $12 \mathrm{~h}$. The ${ }^{30} \mathrm{Si}$ content of the incubated samples was measured by converting the particulate $\mathrm{SiO}_{2}$ collected on each filter to $\mathrm{BaSiF}_{6}$, which was then analyzed isotopically on a Nuclide Corp. 3-60 (3" radius, $60^{\circ}$ deflection) magnetic sector mass spectrometer as described by Nelson \& Brzezinski (1990). The specific uptake rate of silicic acid $(V)$ at each extracellular substrate concentration was calculated from the ${ }^{30} \mathrm{Si}$ enrichment of the particulate silica as described by Nelson \& Goering (1977). Because $\mathrm{Si}(\mathrm{OH})_{4}$ taken up by diatoms can be deposited as siliceous hard parts within minutes (e.g. Darley et al. 1976), $V$ measured in an incubation experiment of several hours duration represents the overall rate of silicification rather than transport across the cell membrane or any other single step in the process. This is the same operational definition 

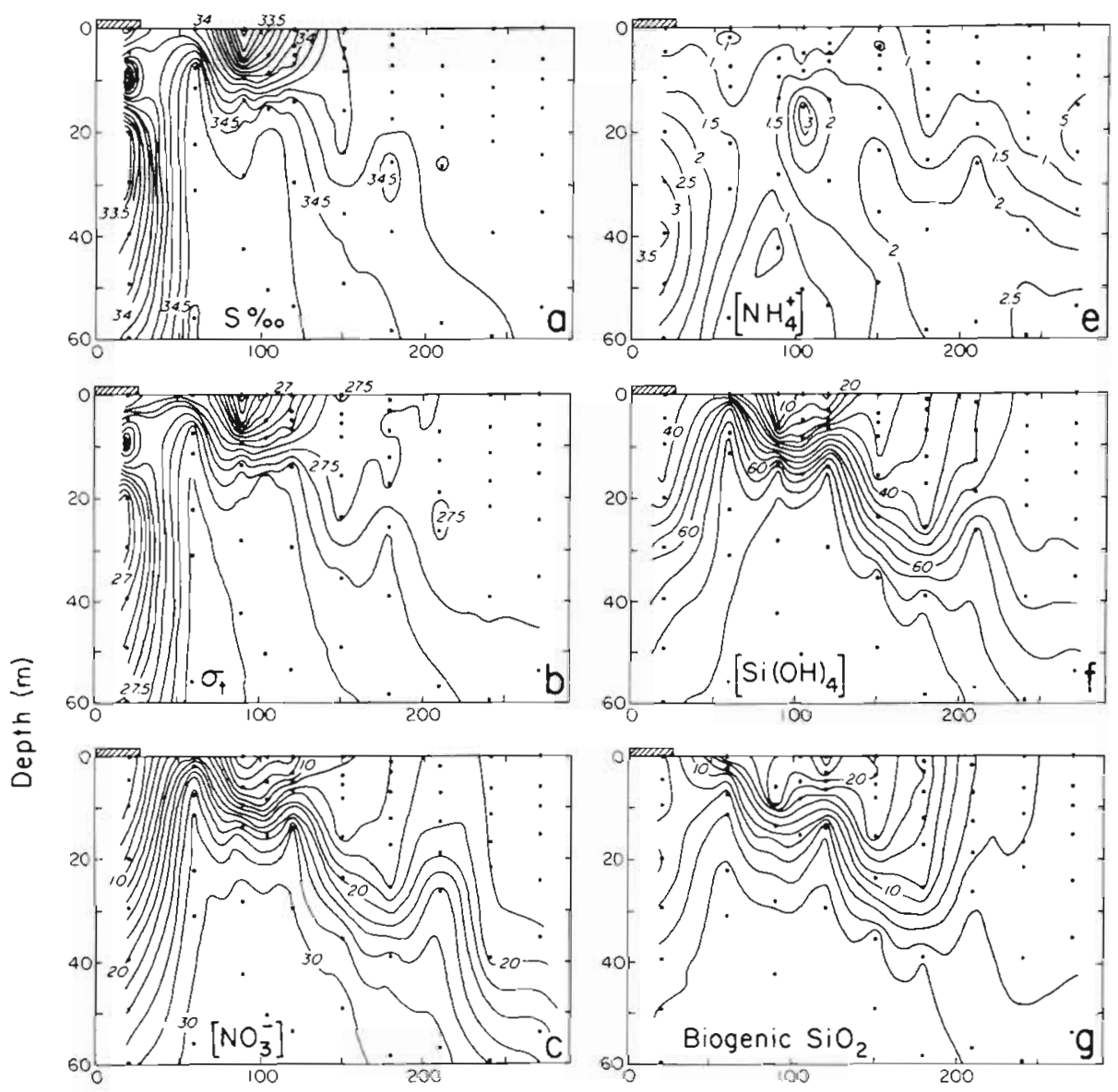

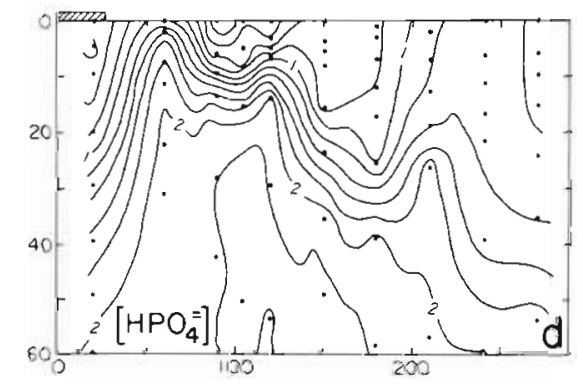

Distance from coost $(\mathrm{km})$
Fig. 2. Distributions of (a) salinity, (b) density, (c) nitrate, (d) phosphate, (e) ammonium, (f) silicic acid and (g) biogenic particulate silica in the upper $60 \mathrm{~m}$ along the transect line shown in Fig. 1 Units: salinity, \%o; density anomaly, $\sigma_{1}, \mathrm{~kg} \mathrm{~m}^{-3}$; and all others, $\mu \mathrm{mol} \mathrm{l}^{-1}$. Bar in upper left of each panel denotes approximate location of ice edge. The 3 stations where ${ }^{30} \mathrm{Si}$ kinetic experiments were performed were all in the area of greatest nutrient depletion 85 to $110 \mathrm{~km}$ from the coast of the term 'uptake' used in all previous laboratory and field studies of Si uptake kinetics (e.g. Paasche 1973b, Azam \& Chisholm 1976, Nelson \& Brzezinski 1990), but differs from that used in physiological studies of membrane transport (e.g. Sullivan 1977, Werner 1977). Precision of the mass-spectrometric measurement of ${ }^{30} \mathrm{Si}$ for these samples was \pm 0.03 at. \%, which translates into an uncertainty in $V$ that ranged from $\pm 0.8 \%$ to $\pm 5.3 \%$ over the range of ${ }^{30} \mathrm{Si}$ enrichments measured.

A separate 1.0 l subsample was collected and filtered immediately through a $0.6 \mu \mathrm{m}$ Nuclepore filter for analysis of biogenic and lithogenic particulate silica. These samples were dried and stored as de- scribed above for incubated samples. Biogenic and lithogenic silica were determined by sequential digestion in $0.2 \mathrm{M} \mathrm{NaOH}$ at $100^{\circ} \mathrm{C}$ and $2.9 \mathrm{M} \mathrm{HF}$ at room temperature, as described by Brzezinski \& Nelson (1989). All values of $V$ were corrected for the contribution of lithogenic silica (Brzezinski \& Nelson 1989), but this correction was $<2 \%$ in all cases as a consequence of the very high biogenic silica concentrations (see 'Results').

For each series of ${ }^{30} \mathrm{Si}$ additions $V$ was plotted as a function of the total extracellular silicic acid concentration (ambient plus added label) and the dependence of $V$ upon $\left[\mathrm{Si}(\mathrm{OH})_{4}\right]$ was described by fitting the 
Table 2. Summary of kinetic data on $\mathrm{Si}(\mathrm{OH})_{4}$ uptake from 3 experiments performed on natural phytoplankton assemblages within an ice-edge diatom bloom in the western Ross Sea. Values in parentheses represent $\pm 95 \%$ confidence limits determined by the nonlinear regression method of Wilkinson (1961)

\begin{tabular}{|c|c|c|c|c|c|c|}
\hline \multirow[t]{2}{*}{ Stn } & \multirow{2}{*}{$\begin{array}{c}\text { In situ } \\
{\left[\mathrm{Si}(\mathrm{OH})_{4}\right]} \\
(\mu \mathrm{M})\end{array}$} & \multirow{2}{*}{$\begin{array}{c}\text { Biogenic } \\
\text { silica } \\
\left(\mu \mathrm{mol} l^{-1}\right)\end{array}$} & \multirow{2}{*}{$\begin{array}{l}V_{\max } \\
\left(\mathrm{h}^{-1}\right)\end{array}$} & \multirow[t]{2}{*}{$\begin{array}{c}k_{m} \\
(\mu \mathrm{M})\end{array}$} & \multicolumn{2}{|c|}{$\begin{array}{c}\text { Calculated } \\
\text { in situ } V\end{array}$} \\
\hline & & & & & $V_{\max }$ & Highest $V$ \\
\hline 173 & 6.0 & 20.3 & $\begin{array}{c}0.00222 \\
( \pm 0.00016)\end{array}$ & $\begin{array}{c}1.11 \\
( \pm 0.90)\end{array}$ & 0.84 & 0.85 \\
\hline 174 & 5.6 & 17.7 & $\begin{array}{c}0.00230 \\
( \pm 0.00010)\end{array}$ & $\begin{array}{c}2.37 \\
( \pm 0.61)\end{array}$ & 0.70 & 0.76 \\
\hline 175 & 6.6 & 24.6 & $\begin{array}{c}0.00283 \\
\pm 0.00023)\end{array}$ & $\begin{array}{c}4.58 \\
( \pm 1.42)\end{array}$ & 0.59 & 0.71 \\
\hline
\end{tabular}

Michaelis-Menten equation (Eq. 1) to the data. The kinetic parameters $V_{\max }$ and $k_{\text {m, }}$ and their $95 \%$ confidence limits, were calculated by the nonlinear regression method of Wilkinson (1961).

\section{RESULTS}

The salinity, nutrient and biogenic silica distributions prevailing in the study area on 3 \& 4 February are shown in Fig. 2. The ice-edge diatom bloom was quite intense, with biogenic silica concentrations exceeding $20 \mu \mathrm{mol} \mathrm{l}^{-1}$ within the core of the meltwater lens. Silicic acid, nitrate and phosphate concentrations were all much lower within the bloom than in the surrounding and underlying waters, with minimum concentrations of $5.4,2.3$ and $0.18 \mu \mathrm{M}$, respectively. There was a subsurface (20 to $60 \mathrm{~m}$ ) maximum in ammonium throughout the study area, within which the concentration generally exceeded $2 \mu \mathrm{M}$; surface-layer ammonium concentrations were 0.7 to $1.0 \mu \mathrm{M}$ in the vicinity of the ice edge and 0.5 to $0.6 \mu \mathrm{M}$ in the eastern part of the transect. Surface $(1 \mathrm{~m})$ silicic acid concentrations at the 3 locations sampled for ${ }^{30} \mathrm{Si}$ kinetic experiments on 5 February ranged from 5.6 to $6.6 \mu \mathrm{M}$ (Table 2), close to the lowest concentration observed on the transect.
Uptake of silicic acid by the in situ diatom assemblage was detectably substrate-dependent at each of the 3 locations sampled (Fig. 3). The dependence of $V$ on $\left[\mathrm{Si}(\mathrm{OH})_{4}\right]$ appears to have conformed well to the Michaelis-Menten model (Eq. 1) in each of the 3 experiments. Calculated $V_{\max }$ values ranged from 0.0022 to $0.0028 \mathrm{~h}^{-1}$ (Table 2), which corresponds to maximum specific growth rates of 0.08 to 0.10 doublings $\mathrm{d}^{-1}$ for biogenic silica in the surface water. In each of the 3 experiments the calculated $V_{\max }$ exceeded the highest $V$ actually measured by 2 to $20 \%$; this may have resulted from the fact that a rectilinear or truncated-hyperbola model, in which the asymptotic value of $V_{\max }$ (see Eq. 1) is never actually achieved by the cells, is in many cases a more accurate description of Si kinetics at high substrate concentrations than is Eq. (1) (e.g. Nelson et al. 1981, Sommer 1991).

Calculated half-saturation constants for silicic acid uptake $\left(k_{m}\right)$ ranged from $1.1 \mu \mathrm{M}$ at Stn 173 to $4.6 \mu \mathrm{M}$ at Stn 175 (Table 2). Thus the highest $k_{m}$ measured was lower than the lowest ambient silicic acid concentration observed. Evaluation of the MichaelisMenten function (Eq. 1) at the ambient silicic acid concentration at the time of sampling indicates that the diatom assemblages present were capable of
Fig. 3. Concentration-dependence of silicic acid uptake rates by natural diatom assemblages at (a) Stn 173, (b) Stn 174 and (c) Stn 175. Data points show the measured values of $V$ and the fitted curve is the Michaelis-Menten hyperbola obtained by nonlinear regression of Eq. (1) to the data (Wilkinson 1961). Dashed portion of each curve represents the region where Eq. (1) has been extrapolated to silicic acid concentrations below ambient, where no experimental data are available
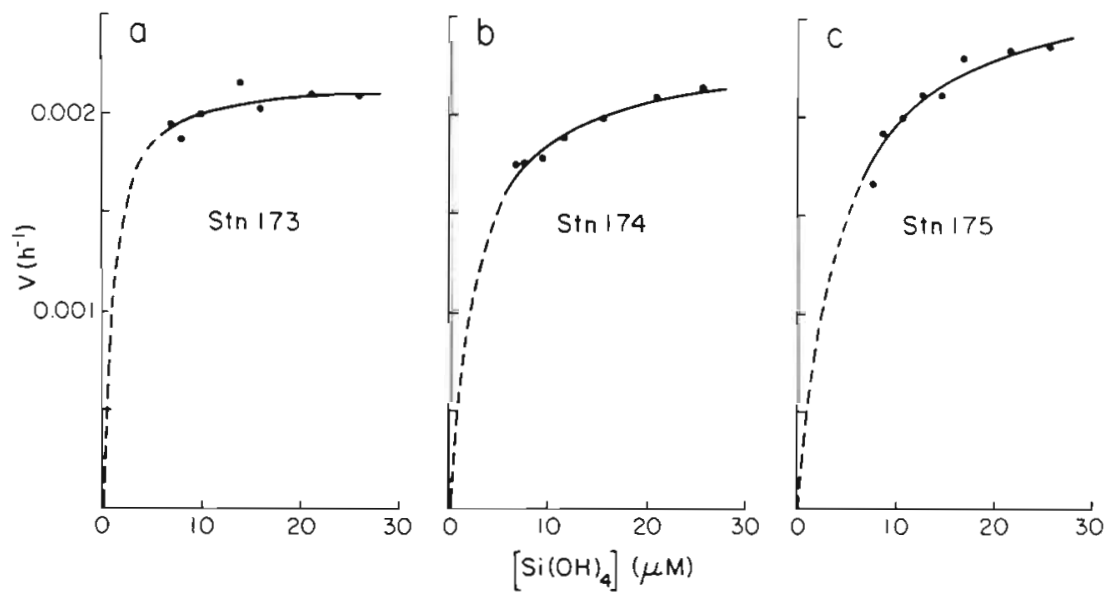
taking up $\mathrm{Si}(\mathrm{OH})_{4}$ at rates ranging from 0.59 to 0.84 of $V_{\max }$ at the in situ concentrations (Table 2). If the $V_{\max }$ calculated by fitting the Michaelis-Menten function to the data exceeds the highest $V$ the cells can achieve, the ratio of the calculated $\mathrm{V}$ at the in situ $\left[\mathrm{Si}(\mathrm{OH})_{4}\right]$ to the highest $V$ measured may be a more accurate measure of the degree of silicon limitation experienced by the cells. This ratio ranged from 0.71 to 0.85 in our experiments (Table 2). Thus the kinetic data indicate that, at the lowest silicic acid concentrations that developed within the core of an iceedge diatom bloom in the Ross Sea in late summer, substrate limitation of silicic acid uptake rate by the in situ diatom assemblage was readily detectable, but not strong.

\section{DISCUSSION}

\section{Maximum uptake rates}

The range of $V_{\max }$ values in our experiments (see Table 2) corresponds to specific growth rates of 0.08 to 0.10 doublings $\mathrm{d}^{-1}$ for biogenic particulate silica. This range agrees well with $V$ values for silica measured throughout the ice-edge diatom bloom in 1990 (Nelson et al. 1991) and in 1983 (Nelson \& Smith 1986). These rates are only about 10 to $15 \%$ of the temperature-controlled upper limit on phytoplankton growth rates at $\mathrm{ca} 0^{\circ} \mathrm{C}$ (e.g. Eppley 1972), and are no higher than specific growth rates reported from much less productive areas of the Southern Ocean (e.g. Smith \& Nelson 1990, Quéguiner et al. 1991\}. The measured doubling rate of biogenic silica can significantly underestimate the average specific growth rate of the diatom assemblage if a substantial fraction of the biogenic silica is composed of nonliving diatoms, empty frustules, siliceous fragments, etc. (Goering et al. 1973). However, the ice-edge bloom in the western Ross Sea was estimated by several methods to have very little $(<10 \%)$ detrital siliceous material of this kind in 1983 (Carbonell 1985, Nelson \& Smith 1986, Wilson et al. 1986) and was again composed almost entirely of living cells in 1990 (A. Leventer unpubl.). Thus the mean specific growth rate of diatoms within the Ross Sea ice-edge bloom appears to have been no higher than 0.1 division $\mathrm{d}^{-1}$, even when silicic acid was added at relatively high concentrations. This observation is consistent with previous conclusions that ice-edge phytoplankton blooms in the Southern Ocean are localized maxima in primary productivity as a consequence of their high biomass, rather than as a result of locally enhanced growth rates of the phytoplankton (e.g Smith \& Nelson 1986. Smith \& Sakshaug 1990).
$V_{\max }$ values that are much lower than the highest specific growth rates that could be sustained at the in situ temperature imply relatively strong limitation of diatom growth rates by some factor other than $\mathrm{Si}$ limitation. While nitrate and phosphate exhibited minima within the core of the ice-edge bloom, as did silicic acid (see Fig. 2) and nutrient depletion of this kind is apparently common in the Ross Sea ice-edge zone in summer (e.g. Nelson \& Smith 1986), the lowest nitrate and phosphate concentrations measured during our study (2.3 and $0.18 \mu \mathrm{M}$, respectively) generally exceeded those shown to limit marine or freshwater phytoplankters in culture studies (e.g. Gotham \& Rhee 1981, Smith \& Kalff 1982, Goldman \& Glibert 1983). The likelihood of significant $N$ limitation is further diminished by the persistence of ammonium concentrations $>0.7 \mu \mathrm{M}$ throughout the study area. However we cannot completely rule out $\mathrm{N}$ or $\mathrm{P}$ limitation in the ice-edge zone of the Ross Sea because no $\mathrm{N}$ or $\mathrm{P}$ kinetic studies have yet examined Antarctic isolates and it is possible that their uptake and growth kinetics differ from those of the species that have been examined. The difference between this situation and that concerning possible Si limitation is that no experimental results showing exceptionally low substrate affinity in Antarctic species have been reported for $\mathrm{N}$ or $\mathrm{P}$ as they have for $\mathrm{Si}$ (see Table 1). Occasional limitation by $\mathrm{N}$ and/or $\mathrm{P}$ in the western Ross Sea is strongly suggested by previous observations, showing much more severe depletion of these nutrients in 1983 than we observed in 1990 (Nelson \& Smith 1986).

The addition of nanomolar concentrations of unchelated iron stimulated the accumulation of phytoplankton biomass in long-term incubation experiments conducted at 3 locations in the Ross Sea during the time of our study (Martin et al. 1990). However, the iceedge bloom in the southwestern Ross Sea, where the experiments reported here were performed, was the 1 site at which the possibility of iron limitation was examined and no response to iron enrichment was observed (Martin et al. 1990). It has also been suggested that the phytoplankton biomass levels and growth rates that can be supported in ice-edge blooms throughout the Southern Ocean may be limited by light as a result of self-shading once chlorophyll levels

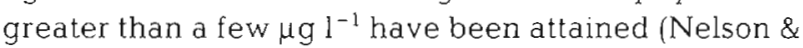
Smith 1992). The results reported here do not address that hypothesis directly. Thus there is no direct evidence that phytoplankton growth was limited to a significant degree by nitrogen, phosphorus, iron or light within the western Ross Sea ice-edge bloom during the time of our observations, but the available data suggest that each may become temporarily or locally limiting within the system. 
Concentration dependence of silicic acid uptake and role of $\mathrm{Si}$ as a limiting nutrient in the Southern Ocean

$V$ increased measurably with increasing $\left[\mathrm{Si}(\mathrm{OH})_{4}\right]$ in each of our 3 experiments (see Fig. 3), and the $V$ vs $\left[\mathrm{Si}(\mathrm{OH})_{4}\right]$ response curves appear to conform approximately to the Michaelis-Menten saturation function (Eq. 1). The calculated $k_{m}$ values are subject to much greater proportional uncertainty than are the $V_{\max }$ values (see Table 2); statistically this is a consequence of the fact that $k_{m}$ was in all cases considerably lower than the ambient $\left[\mathrm{Si}(\mathrm{OH})_{4}\right]$ and thus data could not be obtained over the range of concentrations less than and equal to $k_{m}$. However, the statistical uncertainty in $k_{m}$ is not great enough to obscure 2 clear results: (1) $k_{m}$ values measured in the western Ross Sea are very similar to those reported from relatively nutrientrich surface waters in temperate and tropical regions (see Table 3); and (2) $k_{m}$ values in this natural system are much lower than $k_{m}$ and $k_{s}$ reported for many Antarctic diatoms in culture studies (Jacques 1983, Sommer 1986, 1991; see Table 1).

Comparison of the $V$ vs $\left[\mathrm{Si}(\mathrm{OH})_{4}\right]$ response curves (Fig. 3) and calculated $k_{m}$ values (Table 2) with the observed silicic acid concentration field (Fig. $2 f_{\text {; }}$ see also Nelson et al. 1991) shows that diatoms with $k_{m}$ values comparable to those found in our experiments would have experienced detectable Si limitation only within the central, low-nutrient core of the ice-edge bloom. Certainly no increase in $V$ with increasing $\left[\mathrm{Si}(\mathrm{OH})_{4}\right]$ would have been detectable at any location where the ambient concentration exceeded $20 \mu \mathrm{M}$ (see Fig. 3). A small region, 50 to $80 \mathrm{~km}$ in east-west extent, within which surface $\left[\mathrm{Si}(\mathrm{OH})_{4}\right]$ was depleted to $<20 \mu \mathrm{M}$ persisted through January and early February 1990 in the core of the ice-edge bloom (Nelson et al. 1991), and was also present during late January 1983 (Nelson \& Smith 1986). However this area was bounded by very strong horizontal concentration gradients, and surface $\left[\mathrm{Si}(\mathrm{OH})_{4}\right.$ ] values significantly exceeded $20 \mu \mathrm{M}$ throughout most of the Ross Sea, even during late summer (Nelson \& Smith 1986, Nelson et al. 1991). Thus,

Table 3. Half-saturation constants for silicic acid uptake $\left(k_{m}\right)$ reported for natural phytoplankton assemblages

\begin{tabular}{|lcl|}
\hline Location & $k_{m}(\mu \mathrm{M})$ & Source \\
\hline Ross Sea ice edge & $1.1-4.6$ & This study \\
Peru upwelling region & 2.9 & Goering et al. 1973 \\
& 3.7 & Nelson et al. 1981 \\
Baja California coast & 1.5 & Azam \& Chisholm 1976 \\
Gulf of California & 2.5 & Azam \& Chisholm 1976 \\
Gulf Stream & $0.5-0.9$ & Nelson \& Brzezinski \\
warm-core rings & & 1990 \\
\hline
\end{tabular}

diatoms with Si uptake kinetics similar to those found in our experiments would encounter small, but reasonably persistent, areas of perceptible silicon limitation near the edge of the retreating pack ice in the Ross Sea. This limitation would be rather weak even within the areas where it occurs.

The above conclusion that Si limitation occurs in the Ross Sea, but is localized and not strong, pertains only to diatoms with $k_{m}$ values in the 1 to $5 \mu \mathrm{M}$ range observed in our experiments. Several Southern Ocean diatom species have been reported to have $k_{m}$ or $k_{s}$ values $>12 \mu \mathrm{M}$, and ranging up to $89 \mu \mathrm{M}$ (see Table 1 ). Silicon $k_{m}$ and $k_{s}$ values above $12 \mu \mathrm{M}$ differ dramatically from those reported for temperate, tropical and Arctic diatoms (data from several sources, summarized by Nelson unpubl; see also Table 1). Diatoms with $k_{m}$ and/or $k_{s}$ values comparable to the higher ones shown in Table 1 would experience some degree of Si limitation almost everywhere in the Southern Ocean in summer, and would have been very severely Si-limited ( $V$ would have ranged from 0.06 to 0.32 of $V_{\max }$ ) within the core of the ice-edge bloom in the Ross Sea. Thus, the question of whether Si limitation is of major or minor importance to diatoms in the Southern Ocean hinges on whether the Si kinetics observed in our field experiments or those seen in some of the culture studies are more typical of Antarctic diatoms under natural conditions.

During the time period when our experiments were conducted the phytoplankton within the ice-edge diatom bloom was dominated by 3 species of the genus Nitzschia ( $N$. curta, $N$. cylindrus and $N$. closterium), with $N$. curta accounting for 80 to $90 \%$ of the cells present (A. Leventer unpubl.). Dominance of $N$. curta within the ice-edge bloom in the Ross Sea is apparently very common; this species was observed to dominate an intense bloom in this same area in the summer of 1983 (Carbonell 1985, Wilson et al. 1986) and has been the most abundant species in the sediment record of the western Ross Sea over the past 18000 yr (Kellogg \& Truesdale 1979). During both 1983 and 1990 the abundance of all 3 Nitzschia species decreased rapidly outside the meltwater-influenced region near the ice edge (Carbonell 1985, Leventer unpubl.).

In surface waters 200 to $400 \mathrm{~km}$ east of the ice-edge bloom there were other, less intense maxima in biogenic silica in January and early February 1990 (Nelson et al. 1991). Within these maxima biogenic silica concentrations were typically between 7 and $10 \mu \mathrm{mol} \mathrm{l} \mathrm{l}^{-1}$; these concentrations, although about 3 times lower than the extraordinarily high levels found in the ice-edge bloom, are very high in comparison with those in other areas of the ocean (e.g. Nelson et al. $1981,1987)$. The species composition of the phyto- 
plankton within these secondary biomass maxima differed greatly from that within the ice-edge bloom; it was a mixed assemblage of diatoms and the prymnesiophyte Phaeocystis pouchetii, with Corethron criophilum and a Chaetoceros species the major contributors to the diatom biomass (Leventer unpubl.). The 3 Nitzschia species that comprised most of the ice-edge bloom were all present, but at greatly reduced abundances (Leventer unpubl.). Silicic acid and other nutrients exhibited localized minima within these features, but silicic acid concentrations remained $>40 \mu \mathrm{M}$ throughout these minima (Nelson et al. 1991).

Corethron criophilum has been reported to have a very high $k_{\mathrm{s}}$ for Si-limited growth, in the range of 34 to $60 \mu \mathrm{M}$, and the only Antarctic species of Chaetoceros whose $\mathrm{Si}$ kinetics have been examined to date, $C$. neglectum, had a reported $k_{s}$ of $22 \mu \mathrm{M}$ (Sommer 1986 , 1991; see Table 1). It is thus possible that the diatom species that were most abundant in the high-nutrient surface waters of the southeastern Ross Sea had a much lower affinity for silicic acid than did the Nitzschia species that dominated the bloom at the western ice edge. The growth rates of diatoms with Si-limited growth kinetics similar to those reported for Corethron criophilum and Chaetoceros neglectum would have been severely Si-limited at the $<20 \mu \mathrm{M}$ silicic acid concentrations that characterized the core of the iceedge bloom. In fact, their growth would have been detectably limited even at the 40 to $55 \mu \mathrm{M}$ concentrations present in the surface waters 200 to $400 \mathrm{~km}$ east of the ice edge, where they were found.

Use of culture-derived kinetic parameters for a diatom species to interpret the degree of nutrient limitation experienced by that species or a related species in a given marine habitat involves considerable uncertainty resulting from the great range of genetic and physiological variability that exists both within species and between ecologically similar species (e.g. Gallagher in press). Note, for example, that reported $k_{m}$ and $k_{s}$ values for 3 Antarctic species of Nitzschia range from 8.4 to $88.7 \mu \mathrm{M}$ (Table 1 ) and that all of our $k_{m}$ values from a natural diatom assemblage dominated by 3 Nitzschia species fall below even that very wide range (Table 2). Thus we cannot rule out the possibility that the diatom species that dominated the eastern Ross Sea assemblage were kinetically very different from those we examined near the western ice edge, and were in fact excluded from the ice-edge bloom as a consequence of their low affinity for silicic acid.

The data presented in Fig. 2 support earlier sug. gestions (Nelson \& Smith 1986, Nelson et al. 1991) that ice-edge diatom blooms are common in the western Ross Sea, and that they result in persistent mesoscale areas of significant nutrient depletion. This intensified activity at the first trophic level has been attributed to a combination of factors favorable to the growth and accumulation of phytoplankton, including stabilization of the upper water column by meltwater (Smith \& Nelson 1985), increased trace-element availability (Martin et al. 1990) and diminished grazing pressure resulting from the fact that the ca $600 \mathrm{~m}$ shelf depth precludes reproduction of Euphausia superba and other krill species (El-Sayed 1990). These favorable factors may be widespread over continental shelf areas in the Antarctic, and phytoplankton blooms have been observed in several other nearshore areas around Antarctica (e.g. Holm-Hansen et al. 1989, Dehairs et al. 1991). Thus the Ross Sea is not a unique system, although the large extent and temporal persistence of open water in summer (Zwally et al. 1983) may make it significantly more productive than average for Antarctic coastal waters, as has been indicated by satellite ocean-color images (Yoder et al. 1989). It is in these coastal areas, during times of nutrient depletion brought about by phytoplankton blooms, that Si limitation of diatom growth is most likely to occur; in fact these are the only areas of the Antarctic where diatoms with Si uptake kinetics similar to those reported here would experience measurable Si limitation.

Diatom-dominated phytoplankton blooms also develop in the ice-edge zones of deep-water areas of the Southern Ocean, but in those systems nutrient concentrations remain much higher than those in the core of the Ross Sea bloom (e.g. Nelson et al. 1987, Tréguer et al. 1991). Extrapolation of our kinetic results from the Ross Sea to the $\left[\mathrm{Si}(\mathrm{OH})_{4}\right]$ distributions reported from open-ocean bloom situations suggests that no significant Si limitation would occur, even at the lowest concentrations that have been observed. However, diatom species with very low affinity for silicic acid, such as reported by Jacques (1983) and Sommer (1986, 1991) would be significantly limited by $\mathrm{Si}$ availability in these other systems.

Field data on the concentration dependence of silicic acid uptake by the natural diatom assemblages in open-ocean areas of the Southern Ocean would help to resolve the question of whether $\mathrm{Si}$ is a limiting nutrient in those systems, but the first such data from an Antarctic marine habitat (Fig. 3, Table 2) argue against the hypothesis that Si limitation is strong or widespread in the Antarctic.

Acknowledgements. We thank Julie Arrington, Linda J. Herlihy and Joe C. Jennings, Jr, for their help at sea, and Louis I. Gordon for the nutrient data. Mark A. Brzezinski assisted us in the statistical analysis of data. This research was supported by the US National Science Foundation through Grant \#8817441 to Oregon State University and by the Institut National des Sciences de l'Univers (CNRS, France) 


\section{LITERATURE CITED}

Azam, F., Chisholm, S. W. (1976). Silicic acid uptake and incorporation by natural marine phytoplankton populations. Limnol. Oceanogr. 21: 427-433

Brzezinski, M. A., Nelson, D. M. (1989). Seasonal changes in the silicon cycle within a Gulf Stream warm-core ring Deep Sea Res. 36: 1009-1030

Carbonell, M. C. (1985). Phytoplankton of an ice-edge bloom in the Ross Sea, with special reference to the elemental composition of Antarctic diatoms. M.S. thesis, Oregon State University

Conway, H. L., Harrison, P. J (1977). Marine diatoms grown in chemostats under silicate or ammonium limitation. IV Transient response of Chaetoceros debilis, Skeletonema costatum and Thalassiosira gravida to a single addition of the limiting nutrient. Mar. Biol. 43: 33-43

Darley, W. M., Sullivan, C. W., Volcani, B. C. (1976). Studies of the biochemistry and fine structure of silica shell formation in diatoms: division cycle and chemical composition of Navicula pelliculosa during light:dark synchronized growth. Planta 130: 159-167

Dehairs, F., Stroobants, N., Goeyens, L. (1991). Suspended barite as a tracer of biological activity in the Southern Ocean. Mar. Chem. 35: 399-410

El-Sayed, S. Z. (1990). Plankton. In: Glasby, G. P. (ed.) Antarctic sector of the Pacific. Elsevier, Amsterdam, p. 207-241

Eppley, R. W. (1972). Temperature and the regulation of phytoplankton growth in the sea. Fish. Bull. U.S. 70: 1063-1085

Gallagher, J. C. (in press). The diatoms. In: Alberte, R. A., Barber, R. T (eds.) Marine photosynthesis. Oxford Univ. Press, London

Goering, J. J., Nelson, D. M., Carter, J. A. (1973). Silicic acid uptake by natural populations of marine phytoplankton. Deep Sea Res. 2019): 777-789

Goldman, J. C., Glibert, P. M. (1983). Kinetics of inorganic nitrogen uptake by phytoplankton. In: Capone, D. G., Carpenter, E. J. (eds.) Nitrogen in the marine environment. Academic Press, New York, p. 233-274

Gordon, A. L., Molinelli, E. J., Baker, T N. (1986). Southern Ocean atlas. Columbia Univ. Press, New York

Gotham, I. J., Rhee, G. Y. (1981). Comparative kinetic studies of phosphate-limited growth and phosphate uptake in phytoplankton in continuous culture. J. Phycol. 17: $257-265$

Guillard, R. R. L., Kilham, P., Jackson, T A. (1973). Kinetics of silicon limited growth in the marine diatom Thalassiosira pseudonana Hasle and Heimdal (Cyclotella nana Hustedt). J. Phycol. 9: 233-237

Holm-Hansen, O., Mitchell, B. G. (1991). Spatial and temporal distribution of phytoplankton in the western Bransfield Strait region. Deep Sea Res. 38: 961-980

Holm-Hansen, O., Mitchell, B. G., Hewes, C. D., Karl, D. M. (1989). Phytoplankton blooms in the vicinity of Palmer Station, Antarctica. Polar Biol. 10: 49-57

Jacques, G. (1983). Some ecophysiological aspects of Antarctic phytoplankton. Polar Biol. 2: 27-33

Jacques, G., Tréguer, P. (1986). Les écosystèmes pélagiques marins. II. L'océan antarctique. Masson, Paris

Kellogg, T B., Truesdale, R. S. (1979). Late quaternary paleoecology and paleoclimatology of the Ross Sea: the diatom record. Mar. Micropaleontol. 4: 137-158

Le Jehan, S., Tréguer, P. (1983). Uptake and regeneration $\mathrm{Si} / \mathrm{N} / \mathrm{P}$ ratios in the Indian sector of the Southern Ocean: originality of the biological cycle of silicon. Polar Biol. 2: $127-130$
Martin, J. H., Fitzwater, S. E., Gordon, R. M. (1990). Iron deficiency limits phytoplankton growth in Antarctic waters. Global Biogeochem. Cycles 4: 5-12

Nelson, D. M. Ahern, J. A., Herlihy, L. J. (1991). Cycling of biogenic silica within the upper water column of the Ross Sea. Mar. Chem. 35: 461-476

Nelson, D. M., Brzezinski, M. A. (1990). Kinetics of silicic acid uptake by natural diatom assemblages in two Gulf Stream warm-core rings. Mar. Ecol. Prog. Ser. 62: 283-292

Nelson, D. M., Goering, J. J. (1977). A stable isotope tracer method to measure silicic acid uptake by marine phytoplankton. Analyt. Biochem. 78: 139-147

Nelson, D. M., Goering, J. J., Boisseau, D. W. (1981). Consumption and regeneration of silicic acid in three coastal upwelling systems. In: Richards, F. A. (ed.) Coastal upwelling. Am. Geophys. Union, Washington, D.C., p. 242-256

Nelson, D. M., Goering, J. J., Kilham, S. S., Guillard, R. R. L. (1976). Kinetics of silicic acid uptake and rates of silica dissolution in the marine diatom Thalassiosira pseudonana. J. Phycol. 12: 246-252

Nelson, D. M., Smith, W. O., Jr (1986). Phytoplankton bloom dynamics of the western Ross Sea ice-edge. II. Mesoscale cycling of nitrogen and silicon. Deep Sea Res. 33: 1389-1412

Nelson, D. M., Smith, W. O., Jr (1992). Sverdrup revisited: critical depths, maximum chlorophyll levels and the control of Southern Ocean productivity by the irradiance/ mixing regime. Limnol. Oceanogr. (in press)

Nelson, D. M., Smith, W. O., Jr, Gordon, L. I., Huber, B. A (1987). Spring distributions of density, nutrients and phytoplankton biomass in the ice-edge zone of the Weddell/Scotia Sea. J. geophys. Res. 92: 7181-7190

Nelson, D. M., Smith, W. O., Jr, Muench, R. D., Gordon, L. I., Sullivan, C. W., Husby, D. M. (1989). Particulate matter and nutrient distributions in the ice-edge zone of the Weddell Sea: relationship to hydrography during late summer. Deep Sea Res. 36: 191-209

Olsen, S., Paasche, E. (1986). Variable kinetics of siliconlimited growth in Thalassiosira pseudonana (Bacillariophyceae) in response to changed chemical composition of the growth medium. Br. Phycol. J. 21. 183-190

Paasche, E. (1973a). Silicon and the ecology of marine plankton diatoms. I. Thalassiosira psuedonana (Cyclotella nana) grown in a chemostat with silicate as the limiting nutrient. Mar. Biol. 19: 117-126

Paasche, E. (1973b). Silicon and the ecology of marine plankton diatoms. II. Silicate-uptake kinetics in five diatom species. Mar. Biol. 19: 262-269

Quéguiner, B., Tréguer, P., Nelson, D. M. (1991). The production of biogenic silica in the Weddell and Scotia Seas. Mar. Chem. 35: 449-460

Smith, R. E. H., Kalff, J. (1982). Size-dependent phosphorus uptake kinetics and cell quota in phytoplankton. J. Phycol. 18: $275-284$

Smith, W. O., Jr, Nelson, D. M. (1985). Phytoplankton bloom produced by a receding ice edge in the Ross Sea: spatial coherence with the density field. Science 227: 163-166

Smith, W. O., Jr, Nelson, D. M. (1986). Importance of ice edge phytoplankton production in the Southern Ocean. BioScience 36: 251-257

Smith, W. O., Jr, Nelson, D. M. (1990). Phytoplankton growth and new production in the Weddell Sea marginal ice zone during austral spring and autumn. Limnol. Oceanogr. 35: 809-821

Smith, W. O., Jr, Sakshaug, E. (1990). Polar phytoplankton. In: Smith, W. O., Ir (ed.) Polar oceanography. Academic Press, San Diego, p. 477-525 
Sommer, U. (1986). Nitrate- and silicate-competition among antarctic phytoplankton. Mar. Biol. 91: 345-351

Sommer, U. (1991). Comparative nutrient status and com. petitive interactions of two Antarctic diatoms (Corethron criophilum and Thalassiosira antarctica). J. Plankton Res. 13: $61-75$

Sullivan, C. W. 1977. Diatom mineralization of silicic acid. II. Regulation of $\mathrm{Si}(\mathrm{OH})_{4}$ transport rates during the cell cycle of Navicula pelliculosa. J. Phycol. 13: 86-91

Tréguer, P., Lindner, L., Van Bennekom, A. J., Leynaert, A., Panouse, M., Jacques, G. (1991). Production of biogenic silica in the Weddell-Scotia Seas measured with ${ }^{32} \mathrm{Si}$. Limnol. Oceanogr. 36: 1217-1227

Werner, D. (1977). Silicate metabolism. In: Werner, D. (ed.) The biology of diatoms. Univ. of California Press,

This article was submitted to the editor
Berkeley, p. 110-149

Wilkinson, G. N. (1961). Statistical estimations in enzyme kinetics. Biochem. J. 890: 324-332

Wilson, D. L., Smith, W. O., Jr, Nelson, D. M. (1986). Phytoplankton bloom dynamics of the western Ross Sea ice edge. I. Primary productivity and species-specific production. Deep Sea Res. 33: 1375-1387

Yoder, J. A., Lewis, M. R., Blanchard, P. A., Feldman, G. C. (1989). Ocean color from space. NSF/NASA-sponsored U.S. Global Ocean Flux Study Office, Woods Hole

Zwally, H. J., Comiso, J. C., Parkinson, C. L., Campbell, W. J., Carsey, F. D., Gloersen, P. (1983). Antarctic sea ice, 1973 1976: satellite passive-microwave observations. NASA SP-459, National Aeronautics and Space Administration, Washington, D.C.

Manuscript first received: September 27, 1991

Revised version accepted: January 23, 1992 